\title{
Insulin resistance and compensation in laminitis-predisposed ponies characterized by the Minimal Model
}

\author{
Kibby Treiber', Tanja Hess' ${ }^{1}$, David Kronfeld', Ray Boston², Ray Geor ${ }^{3}$ and Patricia A. Harris ${ }^{4}$
}

Dept. of Animal and Poultry Sciences, Virginia Polytechnic Institute and State University, Blacksburg ${ }^{1}$, Dept. of Clinical Studies, New Bolton Center, Kennett Square USA2, Dept. of Biomedical Sciences, University of Guelph, Canada ${ }^{3}$ and Equine Studies Group, WALTHAM Centre for Pet Nutrition, Melton Mowbray, United Kingdom ${ }^{4}$

\begin{abstract}
Summary
Glucose metabolism in Welsh and Dartmoor ponies and ponies disposed to pasture laminitis was characterized using the Minimal Model of glucose and insulin dynamics. Laminitis-disposed ponies were selected based on farm records of previous disease incidence and nonparallel hoof-lines. All ponies were maintained on pasture and in early March each underwent a frequent sampling intravenous (iv) glucose tolerance test which involved a bolus of $300 \mathrm{mg} / \mathrm{kg}$ glucose followed 20 min later by an iv bolus of $20 \mathrm{mlU} / \mathrm{kg}$ insulin. Sampling began just prior to the glucose dose and continued for $4 \mathrm{~h}$. Glucose and insulin curves were modeled to determine insulin sensitivity, glucose effectiveness, acute insulin response to glucose and disposition index. Ponies with previous incidents of laminitis were less insulin sensitive and demonstrated compensatory insulin hypersecretion compared to ponies not at risk. Management of at-risk ponies to avoid insulin resistance and triggers for insulin secretion could reduce the likelihood of developing clinical laminitis.
\end{abstract}

Keywords: Minimal model, laminitis, insulin resistance, pony, glucose

\section{Charakterisierung der Insulin Resistenz und deren Kompensation durch das Minimal Modell bei Hufrehe-disponierten Ponies}

Bei Welsh- und Dartmoor-Ponies, die bei Weidegang für die Entstehung einer Hufrehe disponiert waren, wurde der Glukosestoffwechsel charakterisiert; hierzu wurde die Dynamik in der Glukose und Insulinhomöostase anhand des so genannten minimalen Modells überprüft. Für die Untersuchung standen 13 nicht tragende Wesh- und Dartmoor-Pony Stuten sowie ein Ponywallach zur Verfügung; die Tiere wurden vor der im März durchgeführten Untersuchung auf einer Weide gehalten. Sieben Stuten galten als anfällig für die Hufrehe (PL) aufgrund einer diesbezüglichen Krankheitsgeschichte und das Auftreten nicht paralleler Linien in der Hufwand. Die übrigen Ponies galten als unverdächtig hinsichtlich der Disposition für Hufrehe (NL). Die Gruppen wurden gepaart nach Rasse und Körperkondition, für die ein "Body-ConditionScore" (BC) mit der Skalierung von 1 bis 9 genutzt wurden. Alle Ponies waren als fett zu beurteilen (BC 7.1 \pm 0.2, von 6-8). Die Ponies wurden einem intravenösen Glukose Toleranz Test mit frequenter Blutentnahme (FSIGT) zwischen 8:00 und 10:00 Uhr unterzogen. Der FSIGT startete mit einer basalen Blutprobenentnahme (0), auf die eine intravenöse Gabe (rasche Applikation per Verweilkatheter) von 300 mg Glukose/kg Körpergewicht folgte. Blutprobenentnahmen erfolgten 1, 2, 3, 4, 5, 6, 7, 8, 10, 12, 14, 16, und 19 Minuten nach der Glukosegabe. Zwanzig Minuten nach der basalen Blutentnahme wurden 20 mlU Insulin/kg Körpergewicht injiziert. Die Blutentnahme wurde sodann fortgesetzt zu 22, 23, 24, 25, 27, 30, 35, 40, 50, 60, 70, 80, 100, 120, 150, 180, 210 , und 240 Minuten nach der Glukoseinjektion. Die Analyse des "minimalen Modells” erfolgte anhand der Glukose- und Insulinkurven zur Beschreibung der Insulinsensibilität (SI) der Glukoseffektivität $(\mathrm{Sg}$ ), der akuten Insulinantwort auf Glukose (AIRg) sowie des Dispositionsindexes (DI). Die Normalverteilung der Daten wurde durch den Shapiro-Wilkes Test geprüft. Der T-Test diente dem Mittelwertsvergleich der Gruppen, teilweise wurde auch der Kruskal-Wallis-Test genutzt. Die SI $\left(L \cdot \min -1 \cdot \mathrm{mU}^{-1}\right)$ war bei PL Ponies $(0,08 \pm 0,03)$ geringer $(P=0,007)$ gegenüber 0,39 \pm 0.07 in NL Ponies. Die Sg war zwischen den Tiergruppen nicht verschieden. In PL-Ponies lag die AlRg (mU/L·min-1) mit $885 \pm 187$ höher $(P=0,045)$ als bei den NL Ponies $(172,7 \pm 48,5)$. Es bestanden keine signifikanten Rassenunterschiede (Welsh- vs. Daartmoor-Pony) bei Sg, SI, oder DI (P > 0.23); In WelshPonies wurden tendenziell höhere AlRg-Werte $(858 \pm 197)$ beobachtet als bei Dartmoor-Ponies $(436 \pm 67 ; \mathrm{P}=0.085)$. Es bestand eine gesicherte Korrelation $(P<0.01, r>0.68)$ zwischen den Parametern des Minimalen Modells und den basalen, als Proxies bezeichneten Werten für RISQI (SI) und MIRG (AIRg), die aus den Ergebnissen der basalen Blutentnahme abzuleiten waren. Dieses ist das erste Experiment, in dem die Insulinresistenz durch eine spezifische, quantitative Methode charakterisiert wurde. Insulinresistenz kann als eine adaptive Strategie in Pferden vorkommen, insbesondere in Angehörigen der Ponyrassen, die sich evolutionär unter kargen Bedingungen entwickelt haben. Die Ponies vorliegender Studie zeigen SI-Werte im Bereich der niedrigsten Quintile gesunder Pferde, wodurch den Ponies bereits einen gewisser Grad einer Insulin Resistenz zuzuschreiben ist. Eine gesteigerte Insulin Sekretion (AIRg) in PL Ponies kompensiert teilweise die verminderte Antwort des Zielgewebes auf Insulin. Zusammen können Insulinresistenz und Kompensation derselben zur Hufrehe beitragen, indem sie Veränderungen des Glukoseangebots für vaskuläre Funktionen signalisieren und für die Entstehung der Hufrehe wirksame Faktoren wie Cyłokine und Wachstumsfaktoren beeinflussen. Zusätzlich kann die Stärkeaufnahme (zum Beispiel über junges kleereiches Gras im Frühjahr) kombiniert mit einer Insulin Resistenz das Hufreherisiko erhöhen. Die Erfassung einer Insulinresistenz, evtl. unter Verwendung so genannter Proxies kann dazu beitragen solche Ponies zu identifizieren, die einem erhöhten Risiko zur Entstehung einer Hufrehe ausgesetzł sind. Dies wiederum ist die Basis sinnvoller Prevention dieser Komplikation.

Schlüsselwörter: Insulin Resistenz, Pony, Pferd, Hufrehe, Glukose Stoffwechsel, Minimal Modell

\section{Introduction}

Laminitis involves separation of laminae of the inner wall of the hoof from the pedal bone resulting in acute and sometimes irreversible hoof damage (Hood 1999). In vitro studies have shown associations between failed glucose metabolism and hoof-wall separation (French and Pollitt 2004, Pass et al. 1998). Few studies have considered glucose and insulin dynamics in laminitis-predisposed ponies (Field and Jeffcott 
1989) and no studies have applied specific quantitative methods to characterize insulin resistance in these ponies.

Recently, specific and statistically derived proxies for insulin sensitivity (SI) and acute insulin response to glucose (AIRg) as assessed by the minimal model of glucose and insulin dynamics (Treiber et al. 2005b) indicated compensated insulin resistance in ponies with a previous history of laminitis compared to those never affected by the disease (Treiber et al. 2005c). To test the validity of these proxies and further characterize glucose metabolism in laminitis-disposed ponies we have applied the minimal model (Hoffman et al. 2003, Treiber et al. 2005a) to 14 ponies having either a history of recurrent laminitis on spring pasture or no history of laminitis.

\section{Materials and Methods}

Thirteen barren Welsh and Dartmoor mares and one Welsh gelding were maintained on pasture until the morning of the study which was performed in the first week of March. Ponies were selected as disposed to laminitis ( $P L, n=7)$ or not predisposed ( $N L, n=7$ ) based on their individual history of laminitis, hoof morphology, and the occurrence of laminitis in members of their pedigree. Ponies were matched for breed and body condition on a scale of 1-9 (Henneke et al. 1983). All ponies were considered overweight $(B C 7.1 \pm 0.2$, range $6-8$ ) and weighed $312 \pm 6 \mathrm{~kg}$. Three $\mathrm{NL}$ and $3 \mathrm{PL}$ ponies were Dartmoor and $4 \mathrm{NL}$ and $4 \mathrm{PL}$ ponies were Welsh. The $\mathrm{NL}$ ponies were younger (median $4 \mathrm{y}$, range $4-6 \mathrm{y}$ ) than $\mathrm{PL}$ ponies (median $8 \mathrm{y}$, range $6-21 \mathrm{y}$ ).

All ponies underwent a frequently sampled intravenous glucose tolerance test (FSIGT) beginning between 8:00 and 10:00 am. The FSIGT began with a basal sample followed by a glucose dose of $300 \mathrm{mg} / \mathrm{kg}$ BW glucose (Dextrose Solution 50\%, Phoenix Pharmaceutical, Inc. St. Joseph, MO) administered rapidly (within $2 \mathrm{~min}$ ) through a venous catheter which defined 0 min of the test. Sampling occurred at 1, 2, 3, 4, 5, $6,7,8,10,12,14,16$, and $19 \mathrm{~min}$. At $20 \mathrm{~min}, 20 \mathrm{mIU}$ insulin/kg BW (Humulin R, Eli Lilly and Company, Indianapolis, IN) was rapidly administered (within $30 \mathrm{sec}$ ) through the catheter. Sampling continued at 22, 23, 24, 25, 27, 30, 35, $40,50,60,70,80,100,120,150,180,210$ and $240 \mathrm{~min}$ post-glucose dose.

Blood samples were immediately transferred to heparinized sample tubes (Vacutainer, Fisher Health Care, Chicago, IL) and placed in ice water until centrifuged at $3000 \mathrm{~g}$ for 10 min. Plasma was removed within 30 min of collection and frozen at $-4^{\circ} \mathrm{C}$ until analysis. Plasma glucose was analyzed by enzymatic assay (Beckman Instruments, Glucose Procedure \# 16-UV, Sigma Diagnostics, St. Louis, MO). Insulin was determined using an radioimmunoassay (Coat-A-Count Insulin, Diagnostic Products, Los Angeles, CA) previously validated for equine insulin (Freestone et al. 1991). The intraassay CV of duplicate samples was $<1 \%$ for glucose and $5 \%$ for insulin.

The minimal model was applied to the glucose and insulin curves using MinMod Millenium (Boston et al. 2003) to calculate SI $\left(\mathrm{L} \times \mathrm{min}^{-1} \times \mathrm{mU}^{-1}\right)$, AIRg $\left(\mathrm{mU} / \mathrm{L} \times \mathrm{min}^{-1}\right)$, glucose effectiveness $\left(\mathrm{Sg}, \mathrm{min}^{-1}\right)$, and disposition index (DI, dimensionless ratio, Bergman 1997). In addition, basal proxies for $\mathrm{SI}$, the reciprocal of the insulin square root index (RISQI) and AIRg, the modified insulin ratio with glucose (MIRG), which were developed for use in horses were evaluated for validity in these pony breeds (Treiber et al. 2005b).

The Shapiro-Wilkes test for normality was applied to the minimal model data. When the assumption of normality was valid, groups were compared by two-sample t-test. When data was not normally distributed, the Kruskal-Wallis test was used. Correlations were determined by simple linear regression with outliers determined by Studentized (jackknifed) residuals. Statistics were performed using Stata software (StataCorp 2003).

\section{Results}

Glucose and insulin curves are shown in Figure 1. Results for the minimal model analysis are shown in Table 1. In PL ponies, SI was 80\% lower ( $P=0.007)$, AIRG 220\% higher ( $P$ $=0.045)$, and $\mathrm{DI} 50 \%$ lower $(P=0.037)$ compared to values for $\mathrm{NL}$ ponies. One pony in the $\mathrm{PL}$ group was determined to be an outlier by Grubb's test for SI ( $Z=5.84, P<$ $0.001)$. One pony in the NL group was determined by Grub$b^{\prime}$ s test to be an outlier for $\operatorname{AIRg}(Z=5.61, P<0.001)$. Both of these ponies were excluded from analysis of DI, which is the product of SI and AIRg.

Age was not correlated to any parameters of the minimal model $(r<0.35$; $P>0.24)$. The $B C$ was also not correlated to any parameters of the minimal model $(r<0.33 ; \mathrm{P}>$ 0.29). There was no breed difference for $\mathrm{Sg}, \mathrm{SI}$ or $\mathrm{DI}(\mathrm{P}>$ 0.23 ), but AIRg tended to be higher in Welsh ponies (858 \pm 197) compared to Dartmoors (436 $\pm 67 ; P=0.085)$. The one gelding was not exceptional for any variable.

Regressions of RISQI on SI and MIRG on AIRg showed significant correlation $(P<0.001, r=0.871$ and $P=0.010$, $r=0.681$, respectively) (Figure 2 ). One horse was an out-

Table 1 Minimal model parameters for Welsh and Dartmoor ponies predisposed to pasture laminitis (PL) or not predisposed to laminitis (NL). Parameter für das Minimalmodell der Glukose- und Insulinreaktionen bei Welsh- und Dartmoor-Ponies ohne bzw. mit einer anamnestisch begründeten Disposition für Hufrehe auf der Weide.

\begin{tabular}{lccc}
\hline Minimal Model Parameter & $\mathrm{NL}$ & $\mathrm{PL}$ & $\mathrm{P}$-value \\
\hline $\mathrm{Sg} \times 10^{2}, \mathrm{~min}^{-1}$ & $1.5 \pm 0.2$ & $1.3 \pm 0.2$ & 0.56 \\
$\mathrm{SI}, \mathrm{L} \mathrm{min}^{-1} \mathrm{mU}^{-1}$ & $0.39 \pm 0.07$ & $0.08 \pm 0.03$ & 0.007 \\
$\mathrm{AIRg}, \mathrm{mU} / \mathrm{L}_{-} \mathrm{min}^{-1}$ & $405 \pm 65$ & $885 \pm 187$ & 0.045 \\
$\mathrm{DI}$ & $172.7 \pm 48.5$ & $84.5 \pm 43.7$ & 0.037 \\
\hline
\end{tabular}



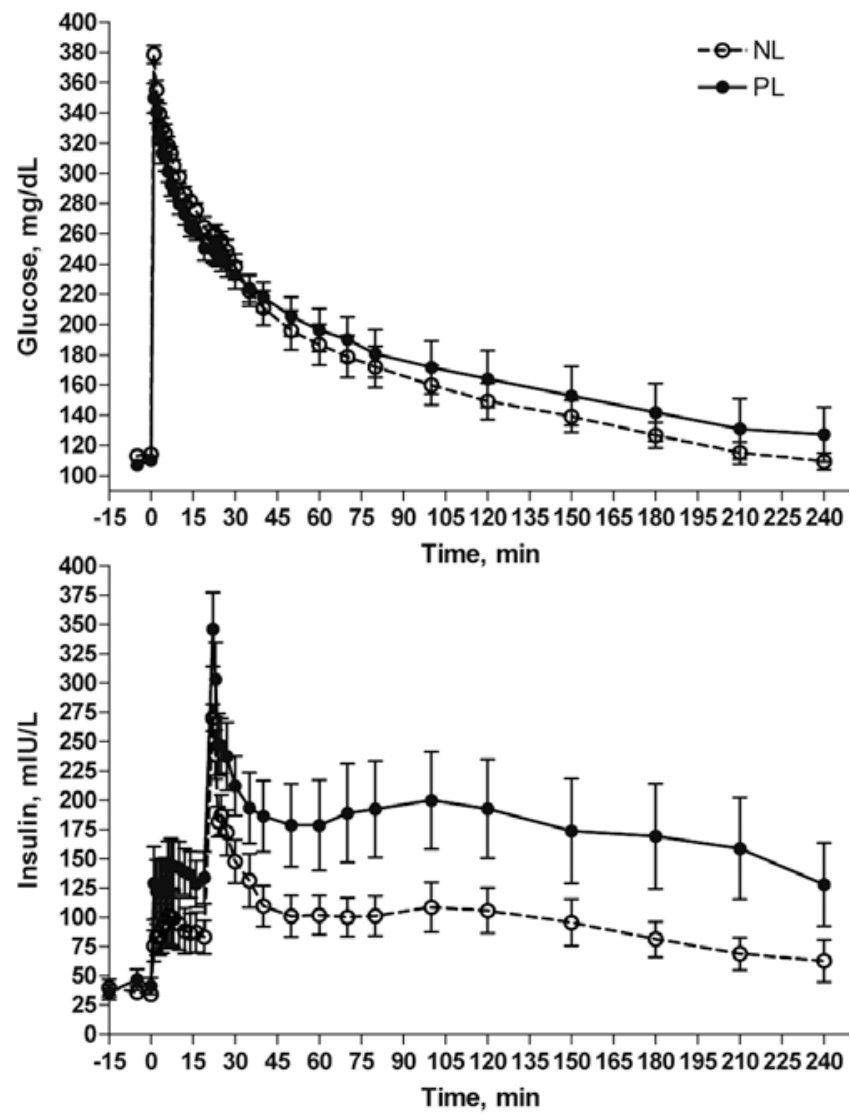

Fig 1 Glucose (a) and insulin (b) curves during the frequent sampling glucose tolerance test for ponies predisposed to laminitis (PL, closed circles) and ponies not predisposed (NL, open circles). Data reported as means \pm standard error.

Konzentrationskurven für Glukose (a) und Insulin (b) im Blutplasma (Mittelwerte \pm Standardfehler) während des Glukosetoleranztestes mit hochfrequenter Probenahme bei Ponies ohne (NL, offene Kreise) bzw. mit Disposition für Hufrehe (PL, gefüllte Punkte)

lier $(P<0.007)$ in both basal insulin and glucose and not included in either regression analysis. Another horse was an outlier for SI ( $P=0.010)$ and removed from the regression of RISQI on SI, although this point had little affect on the goodness-of-fit.

\section{Discussion}

These results demonstrate compensated insulin resistance in ponies predisposed to laminitis, where insulin secretion is increased to compensate for decreased tissue responsiveness to insulin. Also specific proxies for minimal model parameters were shown to be useful predictors of insulin sensitivity and insulin response.

The present study is the first to characterize insulin resistance in laminitis-predisposed ponies using a specific quantitative method. All ponies had insulin sensitivity in the lowest quintile of healthy horses (Treiber et al. 2005b), indicating a general degree of insulin resistance in these pony breeds. Ponies in the PL group, however, had only $1 / 5$ th the insulin sensitivity of NL ponies and this insulin resistance was not associated with age or degree of obesity.
Insulin resistance may decrease glucose availability to insulinsensitive cells, such as laminar basal cells or laminar keratinocytes responsible for laminar tissue turnover (French and Pollitt 2004, Mobasheri et al. 2004). Increased insulin resistance may also alter insulin-mediated affects on blood flow and pressure (Coffman and Colles 1983, Field and Jeffcott 1989, Lind et al. 2000).

Ponies in the NL group had an insulin secretory response similar to that previously reported in obese Thoroughbreds (Hoffman et al. 2003) while the secretory response was more than twofold higher in PL ponies. Increased insulin secretion compensates partially for decreased tissue response to insulin and has been observed in Thoroughbreds, calves and humans (Hoffman et al. 2003, Stanley et al. 2002, Welch et al. 1990). However, insulin is also an important hormone in regulating fat metabolism, growth, and vascular function. Compensatory hyperinsulinemia may therefore be another factor contributing to metabolic disorders such as hyperlipidemia, osteochondrosis and laminitis (Field and Jeffcott 1989, Jeffcott and Field 1985, Ralston 1996). The tendency for Welsh ponies to have higher insulin secretion may place this population most at risk and indicates a possible difference in the expression of 'thriftiness' in particular pony pedigrees (Splan et al. 2005).

In some cases, compensation by increased insulin secretion may not be sufficient to overcome profound insulin resistance and hyperglycemia may result. None of the ponies in this study were hyperglycemic at baseline, however their tolerance of the glucose dose varied. The disposition index, DI, is the product of SI and AIRg and quantifies the effectiveness of an individual's insulin response relative to the insulin sensitivity of their tissue (Bergman 1997). As such, the DI is considered to be an indicator of the risk of developing hyperglycemia.
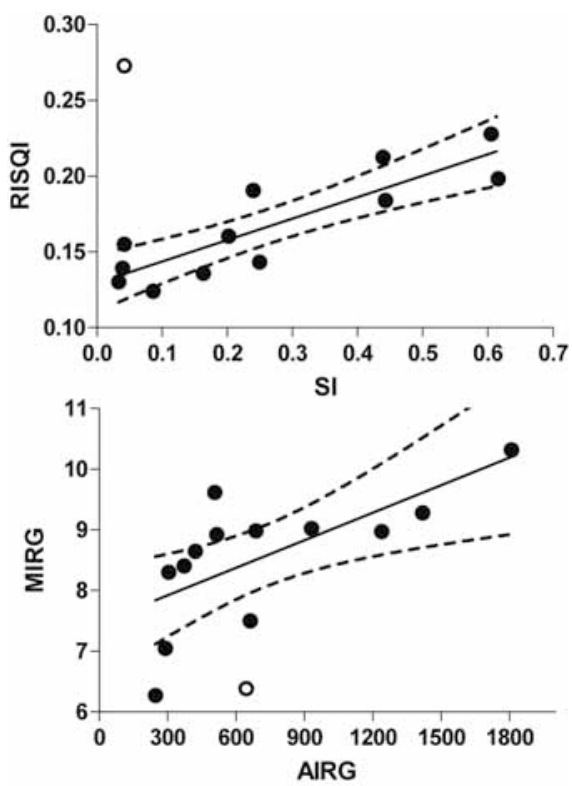

Fig 2 Regressions of RISQI on SI and MIRG on AIRg. The $95 \% \mathrm{Cl}$ is shown by the broken lines. One horse was an outlier for basal values (open circles) and was not included in the regression analysis. Beziehungen der RISQI zu SI sowie von MIRG zu AIRG (gebrochene Linien $=95 \%$ Konfidenzgrenzen; ein als Ausreißer - offener Kreis identifiziertes Tier ist von den Regressionsanalysen ausgeschlossen) 
Despite their greater insulin response, PL ponies had lower DI than NL ponies indicating an additional risk of potential disease. The DI in PL ponies was comparable to that observed in obese Thoroughbreds suggesting that the DI is a weaker discriminator of the laminitis-disposition than insulin insensitivity and compensatory hyperinsulinemia.

The strong correlations in ponies between one-sample basal proxies and SI parameters validate the use of these proxies in a new population of equines. At the same time, one horse was an outlier in both basal measurements and regressions either due to basal sample handling or temporary metabolic perturbation. This example suggests the need for more than one sample to characterize a single case.

Insulin resistance in ponies is an energy-conserving 'thrifty' condition which could be the expression of a 'thrifty genotype' suggested by an identified mode of inheritance (Neel 1962). Animals with the thrifty disposition would have a reduced tolerance for high dietary carbohydrates, and exposure could result in diseases associated with metabolic dysfunction such as hyperlipidemia and especially laminitis (Jeffcott and Field 1985). Certain populations and family-lines expressing this thrifty genotype therefore may have an increased risk of developing laminitis. Management of these individuals to avoid insulin resistance, for example reducing obesity and avoiding of carbohydrate-rich grains or pasture (Hess et al. 2005, Hoffman et al. 2003), could reduce the risk of disease.

\section{Conclusions}

The present study characterizes insulin resistance in two pony breeds, with extreme insulin resistance and compensatory hyperinsulinemia associated with a predisposition for laminitis. Insulin resistance may present an adaptive strategy in populations of equines, particularly pony breeds, which evolved in nutritionally sparse environments. This predisposition may increase the risk of laminitis when insulin resistance and insulin secretion are exacerbated by other factors such as obesity and high-glycemic diets. The present study with the Minimal Model also validates the use of basal proxies for insulin sensitivity and insulin secretion in ponies.

\section{References}

Bergman R. N. (1997): The minimal model: Yesterday, today and tomorrow. In: R. N. Bergman and J. C. Lovejoy (eds.) The minimal model approach and determinants of glucose tolerance. Lovisiana State University Press, Baton-Rouge, 3-50

Boston R. C., D. Stefanovski, P. J. Moate, A. E. Sumner, R. M. Watanabe and R. N. Bergman (2003): Minmod millennium: A computer program to calculate glucose effectiveness and insulin sensitivity from the frequently sampled intravenous glucose tolerance test. Diabetes Technol Ther 5, 1003-1015

Coffman J. R. and C. M. Colles (1983): Insulin tolerance in laminitic ponies. Can J Comp Med 47, 347-351

Field J. R. and L. B. Jeffcott (1989): Equine laminitis-another hypothesis for pathogenesis. Med Hypotheses 30, 203-210

French K. R. and C. C. Pollitt (2004): Equine laminitis: Glucose deprivation and $\mathrm{mmp}$ activation induce dermo-epidermal separation in vitro. Equine Vet J 36, 261-266
Henneke D. R., G. D. Potter, J. L. Kreider and B. F. Yeates (1983): Relationship between condition score, physical measurements and body fat percentage in mares. Equine Vet J 15, 371-372

Hess T. M., D. S. Kronfeld, K. H. Treiber, B. M. Byrd, W. B. Staniar and R. K. Splan (2005): Laminitic metabolic profile in genetically predisposed ponies involves exaggerated compensated insulin resistance. In: Proc. 23rd AAVN/ACVIM Forum, Baltimore MD., 12

Hoffman R. M., R. C. Boston, D. Stefanovski, D. S. Kronfeld and P. A. Harris (2003): Obesity and diet affect glucose dynamics and insulin sensitivity in thoroughbred gelding. J Anim Sci 81, 2333-2342

Hood D. M. (1999): The mechanisms and consequences of structural failure of the foot. Vet Clin North Am Equine Pract 15, 437. 461

Jeffcott L. B. and J. R. Field (1985): Current concepts of hyperlipaemia in horses and ponies. Vet Rec 116, 461-466

Lind L., A. Fugmann, S. Branth, B. Vessby, J. Millgard, C. Berne and H. Lithell (2000): The impairment in endothelial function induced by non-esterified fatty acids can be reversed by insulin. Clin Sci (Lond) 99, 169-174

Mobasheri A., K. Critchlow, P. D. Clegg, S. D. Carter and C. M. Canessa (2004): Chronic equine laminitis is characterised by loss of glutl, glut4 and enac positive laminar keratinocytes. Equine Vet J 36, 248-254

Neel J. V. (1962): Diabetes mellitus: A thrifty genotype rendered detrimental by progress. Am J Human Gen 14, 353-362

Pass M. A., S. Pollitt and C. C. Pollitt (1998): Decreased glucose metabolism causes separation of hoof lamellae in vitro: A trigger for laminitis? Equine Vet J Suppl, 133-138

Ralston S. L. (1996): Hyperglycemia/hyperinsulinemia after feeding a meal of grain to young horses with osteochondritis dissecans (ocd) lesions. Pferdeheilkunde 12, 320-322

Splan R. K., D. S. Kronfeld, K. H. Treiber, T. M. Hess and W. B. Staniar (2005): Genetic predisposition for laminitis in ponies. In: Proc. 19th Conference of the Equine Science Society, Tuscon, Arizona, 219

Stanley C. C., C. C. Williams, B. F. Jenny, J. M. Fernandez, H. G. Bateman 2nd, W. A. Nipper, J. C. Lovejoy, D. T. Gantt and G. E. Goodier (2002): Effects of feeding milk replacer once versus twice daily on glucose metabolism in holstein and jersey calves. J Dairy Sci 85, 2335-2343

StataCorp (2003): Stata statistical software: Release 8.0. Stata Corporation, College Station, TX

Treiber K. H., Boston R. C., Kronfeld D. S., Staniar W. B. and P. A. Harris (2005a) Insulin resistance and compensation in thoroughbred weanlings adapted to high-glycemic meals. J Anim Sci 83, 2357. 2364

Treiber K. H., Kronfeld D. S., Hess T. M., Boston R. C. and P. A. Harris (2005b): Use of proxies and reference quintiles obtained from minimal model analysis for determination of insulin sensitivity and pancreatic beta-cell responsiveness in horses. Am J Vet Res 66, 2114-2121

Treiber K. H., D. S. Kronfeld, T. M. Hess, B. M. Byrd and R. K. Splan (2005c): Pre-laminitic metabolic syndrome in genetically predisposed ponies involves compensated insulin resistance. In: Proc. 23rd AAVN/ACVIM Forum, Baltimore MD, 11

Welch S., S. S. Gebhart, R. N. Bergman and L. S. Phillips (1990): Minimal model analysis of intravenous glucose tolerance test-derived insulin sensitivity in diabetic subjects. J Clin Endocrinol Metab 71, 1508-1518.

Kibby Treiber

5527 Sullivan's Mill Road

Middleburg, VA

USA

ktreiber@vt.edu 